\title{
Analysis of Earnings Management and the Estimation Models in Earnings Management
}

\author{
Xiaohui Liu ${ }^{1}$ \\ ${ }^{1}$ Australia National University, Canberra, Australia \\ Correspondence: Xiaohui Liu, Australia National University, Canberra, Australia. Tel: 61-414-025-905.
}

Received: October 22, 2019

Accepted: November 14, 2019

Online Published: December 14, 2019

doi:10.20849/abr.v4i3.682

URL: https://doi.org/10.20849/abr.v4i3.682

\begin{abstract}
This paper analyzes critically the early and recent literature on earnings management. I summarize the motivations and estimation models for accrual earnings management and real earnings management. Specifically, I focus on estimation models in real earnings management which are developed by Vorst (2016), extending the original sample period. Cross-sectional analysis reveals that earnings management is detectable purely based on companies' financial data. The analyses are of interest to investors, regulators, and researchers with respect to the identification and consequences of earnings management.
\end{abstract}

Keywords: accrual earnings management, real earnings management, operating performance

\section{Introduction}

Earnings management occurs when managers deliberately alter firms' operations or make accounting choice for accruals, which are reflected as real earnings management and accrual earnings management, respectively. Earnings management can be influential, even mislead some stakeholders (Healy and Wahlen 1999).

In essence, earnings management can be deemed as a means of profit manipulation. However, profit manipulation is a kind of fraud through illegal means, which artificially increases or decreases profits. Earnings management, on the other hand, through appropriate accounting policies to seek financial results in favor of themselves within the limits allowed by accounting standards and accounting systems. The objective of this paper is to analyze the earnings management critically by focusing on three main aspects in this topic. The first aspect is about seven possible motivations for earnings management and the relationship between each motivation and manager's behavior in firms. Secondly, we compare various detect earning management method such as the Healy model, the DeAugelo model, the Jones model and modified Jones model to detect accrual-based earning management. Finally, I follow Roychowdhury (2006) and Gunny (2010) to detect real management but extending the original sample period.

The reminder of this paper is organized as follows. Section II provides the background and motivations for earnings management in great detail. Section III discusses estimation models regard to accruals management. Section IV replicates the empirical models used to detect real earnings management and describes the data and methodology, and Section V concludes the paper.

\section{The Motivations for Earnings Management}

\subsection{Debt Covenants}

Debt covenants are commitments offered by the borrower. In order to protect the benefit of debtholders, these commitments (e.g., covenants) specifically limit borrowers from taking specific actions. For example, the company cannot extend dividend excessively, and individuals cannot make additional loans. Some empirical evidence suggests that managers usually manage earnings to smooth income (Buckmaster 2001) and to avoid violating debt covenants (Jaggi and Lee 2002) because debt covenant violations will increase debt capital cost (Chava and Roberts 2008). According to Dicheve and Skinner (2002), managers change their financial reporting decisions to reduce the likelihood of a breach of the debt agreement. All above these prompts managers manipulate earnings to reduce the chance of breaching debt covenants (Watts and Zimmermann 1986). Managers Change the figure of the financial reports to ensure companies can continuously follow the restrictive debt contract. Therefore, earnings management becomes an effective instrument to reduce the possibility of breach of contract. 
Companies have more liability than before when the debt/ equity ratio is high, and managers are more likely to increase income or smooth income. They could manipulate income upwards in bad years and smooth or cut income in good years. They may show the good financial reports to debtholders to prove that they have ability for debt payment in the financial years, showing their purposes in fulfilling restrictive debt covenants. From the debtors perspective, maintaining the long-term relationship with each other can protect their common interest (Anderson, Banker, and Jankiraman 2003), which is particularly sensitive for firms using earnings management to mitigate problems related to leverage (Prencipe, Markarian and Pozza 2008). Meanwhile, debt covenants not only protect the interest of creditors, but providing security to bondholders. It would lead to the organization being able to attract debt at a lower cost, and bondholders are less at risk, because debt covenants limit the ability of owners and managers. For example, paying excessive dividends to owners and diluting the debt of bondholders.

Moreover, there is another case of debt covenants. Before signing a debt contract, debtholders strictly scrutinize debtors according to their financial status and operating results. Considering there are many restrictions need to follow, earning management occurs when enterprises hope to maintain normal business development and seize good market opportunities, which means the financial status and operating results of the enterprise can meet the requirements of creditors through earnings management.

\subsection{Political Costs}

Relevant accounting data of some industries such as banking and insurance are facing strict regulations and controlled by government and lobby groups. The bank must hold the certain proportion of capital requirement and insurance regulation requires the insurance enterprise to achieve the financial health condition of certain degree. The rules give managers strong incentives to whitewash earnings and balance sheets to counter regulation. Besides, other firms seek for government help and protection may also have incentives to manage their earnings to meet certain requirements.

According to Watts and Zimmerman (1990), large firms are more likely to use accounting method to reduce profits of company in the financial reports because they subject to greater political costs. Reducing profits in the report could reduce the possibility that the group is exploiting other parties. Another fundamental reason of reducing profits is that many politicians may take actions against large companies in order to get more trust and support on election. For example, firms such as monopoly enterprises earn enormous profits are typically unpopular among members of constituency. If firms are focused by government political scrutiny, they will pay higher costs and bear the risk of illegal crime. Legoria (1997) claims that many managers of pharmaceutical firms manipulate earnings via discretionary accruals to avoid the major threat by health care reform. Similarly, in order to reduce political costs generated by potential adverse political actions, oil firms engage in earnings management to decrease their profits in financial reports (Hang and Wang 1998). In short, companies are feared by attention, so managers manipulate accounting procedures and manage earnings to relieve the pressure from political parties.

\subsection{Analyst Earnings Forecast}

The analyst earnings forecast is an important earnings benchmark that companies are trying to meet or exceed. Companies can meet or exceed analyst forecast by managing earnings or providing earnings guidance (Lin 2006). For investors, they wish to monitor companies through earnings data come from financial reports. Most external investors realize the potential profitability of the company from financial reports. Mills and Schmidt (2012) state that one of the benchmarks is hitting or satisfying analysts' forecasts, which allows investors to see the company has ability to get profit in future. If the company performance goes beyond the analyst earnings forecasts, more investors will invest their money to the company, which provides more chance for development and more opportunities to achieve future goals. In other words, managers are willing to make the report more "beautiful" in order to beat the analysts' expectation when the actual performance is close to analysts' forecasts. However, the relation between earnings management and analyst forecasts is a controversial issue. Some empirical evidence suggests that there is a weak or no relationship between earnings management and beating analysts' earnings forecasts (George 1988, Lin 2006).

In addition, analysts may not be aware of the impact of earnings management and earning management on current earnings, which leads to a systematic over-valuation or under-valuation of stocks.

\subsection{Tax Avoidance}

Tax payment is always the responsibility and obligation of all enterprises. However, some enterprises reduce the amount income tax through some accounting methods or measures, which can reduce enterprise pressure. 
According to Dhaliwal, Gleason and Mills (2003), corporations will through certain measures to decrease income tax to achieve the profit target when the earning management of non-taxable items cannot bring enough profit. And there is a positive correlation between earnings management and tax avoidance (Wang and Chen 2012). It means when the company have good performance and financial reports, the tax avoidance motivation for earnings management is weak. Similarly, Gonchanalyze and Zimmermann (2006) investigate the influence of tax legislation on earnings management, and they find that Russian companies prefer to use earnings management by reporting small benefits after analyzing the financial reports and firm's behavior of 197 firms. Incentives of tax- avoidance are more likely to affect practices of earnings management (Coppens and Peek 2005).

\subsection{Bonus Scheme}

Bonus scheme is a means which a company uses to match a manager's performance with the amount of bonus they can get. Bonus varies with their performance. Based on agency theory, managers are driven by self-interest, and they have motivations to seek for optimal benefits. Under some circumstances, managers exaggerate their performance to get bonus.

Lots of studies provide evidence that managers manage earnings to maximize bonus payoffs (Cheng and Warfield 2005). As in most bonus contracts, the payments and firm's financial performance are significantly and positively related, which indicates that managers are apt to increase earnings and avoid earnings decrease by engaging in either accrual earning management or real earning management (Dichev and Burstahler 1997). The focus here is not amount but the direction. Bonus schemes usually specify the upper and lower bound: no bonus paid to managers until the reported earnings falls within the range between lower and upper bound (Murphy 1999).

There are several situations regarding to how managers manipulate earnings. In the first place, if managers perceive the current earnings is significantly below the 'lower bound' they manage earnings downwards, that is managers process income decreasing accruals (Healy 1985, Holthausen, Larcker, and Sloan 1995). Managers' choice to 'take a bath' mainly due to that the accruals in the current year will be reversed in subsequent years. In another word, they pin hopes on next periods' earnings to make sure the following years' earnings meet the lower bound of bonus scheme. In the next place, when reported earnings falls within the range between lower and upper bound, the relative degree of managers who are willing to engage in income increasing accruals may differ based on different pay-performance structures specified in bonus schemes. More specifically, it depends on how much extra benefits managers can get when the reported earnings increase at the same amount (Kim and $\mathrm{Ng}$ 2018). Finally, when managers perceive the current earnings for the current period is above the upper bound, they process income decreasing accruals to subsidize the next period's earning level (Healy 1985, Gaver et al, 1995; Holthausen et al, 1995). That is, current earnings are saved for the future (DeFond and Park 1997).

\subsection{CEO Tenure}

CEOs have motivations to manage earnings in early years and last few years during CEO tenure (Ali and Zhang 2015).

Previous studies find new CEOs are more likely to overstate the expenses and losses and blame them to their predecessors in their first year of service. That means they manipulate earnings downward in early years therefore they can take credit for the higher earnings in the following years (Strong and Meyer 1987; Elliott and Shaw 1988; DeAngelo 1988; Pourciau 1993). However, the findings are controversial; an opposite argument is market is uncertain about new CEOs' ability. Thus, new CEOs exercise income-increasing accruals to exaggerated earnings and favorably influence the market's perception (Ali and Zhang 2015).

Additional, when CEOs approach retirement, they are more concern about their final year compensation rather than firms' future performance. Based on the bonus scheme motivation, CEOs always try to maximize the bonus payments. Again, annual bonus is tied to their current year's performance. There are stronger incentives for CEOs to overstate earnings in the final year of service to increase their final year pay, which is consistent with horizon problem (Dechow and Sloan 1991; Pourciau 1993; Murphy and Zimmerman 1993; Cheng 2004; Kalyta 2009).

In summary, during the different stages of CEO tenure, the incentive to manage earnings changes and the relative degree for CEOs to engage in earning management is greater in CEOs' early years of service than in later years (Ali and Zhang 2015).

\subsection{CEO Turnover}

According to Hazarika, Karpoff, and Nahata (2011), firms' earning management also positively associated with 
the speed and likelihood of forced CEO turnover, but there is no such relation when CEO turnover is voluntary.

When CEOs perceive the turnover is approaching, they tend to overstate the earnings because of the presence the profit-based bonus plan (Davidson et al. 2007). CEOs have incentives to boost short term earnings even these managerial decisions may sacrifice future economic benefits. For example, they reduce investments in research and development project, which is similar to the situation when CEOs are about to retirement. Another explanation is CEOs tend to obtain the higher turnover risk compensation.

\section{Detecting Accrual Earnings Management}

It is important for investors and other stakeholders to recognize whether managers engage in earnings management. It is impossible to detect their managerial behaviors merely by observing the financial reports, because managers prefer to hide managerial actions rather than disclose them. Therefore, it requires some heuristics to detect earning management.

Numerous previous studies focus on detecting accrual earnings management. The commonly start point is to get estimate total accruals component of firms' net profit (i.e., TA= Net Profit- Cash Flows). The next step is to decompose total accruals into discretionary accruals component and non-discretionary accruals component (i.e., $\mathrm{TA}=\mathrm{NDA}+\mathrm{DA}$ ). Basically, detecting the earning management is equivalent to identifying the discretionary accruals component, because this part cannot be explained by referring to economic fundamentals. Most of detecting models require at least one known parameter which can be obtained by using 'estimation period' (Dechow and Sloan 1995).

\subsection{The Healy Model}

Healy (1985) detects accrual earnings management by comparing total accruals with three groups of variables: two groups predicted to use income-increasing accruals and one group manage earnings downward. Healy found total accruals represent the measure of nondiscretionary accruals. The model implied as follows:

$$
N D A_{\tau}=\frac{\sum T A_{\mathrm{t}}}{\mathrm{T}}
$$

\subsection{The DeAngelo Model}

This model uses the last period's total accruals as a proxy for non-discretionary accruals. The DeAngelo Model can be deemed as a special case of Healy model.

$$
N D A_{\tau}=T A_{\tau-1}
$$

But it is notable that in the first two models, an important assumption is that non-discretionary accruals are constant, which is seldom holding as a practical matter (DeAngelo 1986).

\subsection{The Jones Model}

Jones 1991 model relaxes the assumption and controls for the key economic changes that affect non-discretionary accruals to get estimation:

$$
\begin{gathered}
\mathrm{NDA}_{\tau}=\alpha_{1}\left(1 / \mathrm{A}_{\tau-1}\right)+\alpha_{2}\left(\Delta \mathrm{REV}_{\tau}\right)+\alpha_{3}\left(\mathrm{PPE}_{\tau}\right) \\
\mathrm{TA}_{\tau}=\mathrm{a}_{1}\left(1 / \mathrm{A}_{\tau-1}\right)+\mathrm{a}_{2}\left(\Delta \mathrm{REV}_{\tau}\right)+\mathrm{a}_{3}\left(\mathrm{PPE}_{\tau}\right)+\gamma_{\mathrm{t}}
\end{gathered}
$$

The error term in the second equation represents for the discretionary accruals that used for detecting earning management. The assumption of Jones model is that the revenues are non-discretionary, but it is questionable by considering such situation: when managers have not received cash yet they accrue revenues at the end of the year it is hard to identify whether the revenues have been earned or not. This managerial discretion increase both total accruals and revenues. It leads to the estimate of earnings management (DA) to be biased toward 0 (Jones, 1991).

\subsection{Modified Jones Model}

The modified Jones model solves the problem in Jones model when managerial discretion processed over revenues.

$$
\mathrm{NDA}_{\tau}=\alpha_{1}\left(1 / \mathrm{A}_{\tau-1}\right)+\alpha_{2}\left(\Delta \mathrm{REV}_{\tau}-\Delta \mathrm{REC}_{\tau}\right)+\alpha_{3}\left(\mathrm{PPE}_{\tau}\right)
$$

Unlike the Jones model which assumes no discretions exercised over revenues, modified Jones model adjusts changes in revenues to the changes in receivables. It implicates that managers exercise accrual earning management over credit-sales part (receivables) of total revenues not cash-sales revenues. Coefficients (i.e., 
$\left.\alpha_{1}, \alpha_{2}, \alpha_{3}\right)$ represent the average sensitivity of total accruals to economic factors among the industries. Non-discretionary accruals, which are firm's expected accruals, can be calculated via modified Jones model. The difference between total accruals and non-discretionary accruals are discretionary accruals. The positive figure means managers exercise earning increasing accruals and the negative figure indicate that firms has been managing earnings downwards (Jones 1991).

In conclusion, Dechow and Sloan (1995) assess different detecting models regarding to their abilities to detect earning management. They find the modified Jones model developed provides the most powerful tests of earnings management and they provide strong empirical evidence support their finding.

\section{Detecting Real Earnings Management}

Most of studies detect accrual earning management as I mentioned above. But evaluate earnings management by analyzing only accruals-based management is probably improper. Again, managers also have motivations to manipulate real activities. Recent studies that examine real earnings management concentrate mostly on manipulating investment activities, which means the firms deliberately alter expenditures on some investments to effect accounting numbers refers to earnings.

Vorst (2016) develops an empirical method to detect real earning management by estimating the normal level of some types of expenditure (e.g., R\&D expenditure) and compares these figures with actual figures reported in financial statements. The residuals of the model are abnormal expense and also are the proxy of real earnings management.

I follow Vorst (2016) and use the following models to estimate real earnings management:

$$
\begin{aligned}
& R \& D_{t} / A_{t-1}=\alpha_{0}+\alpha_{1} 1 / A_{t-1}+\beta_{1} \text { MCAP }_{t}+\beta_{2} \text { TOBINSQ }_{t}+\beta_{3} \text { INTFUNDS }_{t} / A_{t-1} \\
& +\beta_{4} R \& D_{t-1} / A_{t-1}+\varepsilon_{t} \\
& S G \& A_{t} / A_{t-1}=\quad \alpha_{0}+\alpha_{1} 1 / A_{t-1}+\beta_{1} M C A P_{t}+\beta_{2} \text {TOBINSQ }_{t}+\beta_{3} \text { INTFUNDS }_{t} / A_{t-1} \\
& +\beta_{4} \Delta S A L E_{t} / A_{t-1}+\beta_{5} \Delta S A L E_{t} / A_{t-1} * N E G D S A L E_{t}+\varepsilon_{t}
\end{aligned}
$$

The independent variables are designed to control for the factors that can directly influence the normal level of R\&D expenditure based on prior studies. $M C A P_{t}$ controls for the firm size. TOBINSQ $Q_{t}$ controls the growth opportunity for investment because firms with more investment opportunities are more likely to spend more money on R\&D investment. INTFUNDS $S_{t}$ is the internal fund which represents the extent to which firms have to rely on external financing to fund investment project. I control for internal funds because previous studies find the R\&D investment is positively associated with the level of cash flows (Brown and Petersen 2009). The level of last year's $R \& D$ investment is also included to control for the firm's general tendency to invest in R\&D activities. The results of estimating real earnings management models are reported in Appendix A.

\section{Conclusion}

This paper reviews early and recent literature on earnings management. I outline seven motivations (i.e., debt covenants, political costs, analyst forecasts, tax avoidance, bonus scheme, CEO tenure, and CEO turnover) for earnings management and common estimation models to detect earnings management. I focus on estimation of the real earnings management models and extend the sample period. The results are generally as expected and similar to those reported in previous studies.

\section{References}

Ali, A., \& Zhang, W. (2015). CEO tenure and earnings management. Journal of Accounting and Economics, 59(1), 60-79.

Anderson, R. C., Mansi, S. A., \& Reeb, D. M. (2003). Family founding ownership and the agency cost of debt. Journal of Financial Economics, 68, 263285.

Buckmaster, D. (2001). Development of the income smoothing literature 1893-1998: A focus on the United States. Oxford, UK: Elsevier Science Ltd.

Burgstahler, D., \& Dichev, I. (1997). Earnings management to avoid earnings decreases and losses. Journal of Accounting and Economics, 24(1), 99-126.

Chava, S., \& Roberts, M.R. (2008). How Does Financing Impact Investment? The Role of Debt Covenants. The Journal of Finance, 63(5), 2085-2121.

Cheng, Q., \& Warfield, T. D. (2005). Equity incentives and earnings management. The Accounting Review, 80(2), 441-476. 
Cheng, S. (2004). R\&D expenditures and CEO compensation. The Accounting Review, 79(2), 305-328.

Comprix, J., Mills, L.F., \& Schmidt, A.P. (2012). Bias in Quarterly Estimates of Annual Effective Tax Rates and Earnings Management. The Journal of American Accounting Association, 34(1), 31-53.

Coppens, L., \& Peek, E. (2005). An analysis of earnings management by European private firms. Journal of International Accounting, Auditing and Taxation, 14(1), 1-17.

DeAngelo, L.E. (1986). Accounting numbers as market valuation substitutes: A study of management buyouts of public stockholders. Accounting review, 400-420.

DeAngelo, L.E. (1988). Managerial competition, information costs, and corporate governance: The use of accounting performance measures in proxy contests. Journal of accounting and economics, 10(1), 3-36.

Dechow, P.M., \& Sloan, R.G. (1991). Executive incentives and the horizon problem: An empirical investigation. Journal of accounting and Economics, 14(1), 51-89.

Dechow, P.M., Sloan, R.G., \& Sweeney, A.P. (1995). Detecting earnings management. Accounting Review, 193-225.

DeFond, M.L., \& Park, C.W. (1997). Smoothing income in anticipation of future earnings. Journal of accounting and economics, 23(2), 115-139.

Dicheve, L.D., \& Skinner, D.J. (2002). Large-Sample Evidence on the Debt Covenant Hypothesis. Journal of Accounting Research, 40(4), 1091-1123.

Elliott, J.A., \& Shaw, W.H. (1988). Write-offs as accounting procedures to manage perceptions. Journal of Accounting Research, 91-119.

Gaver, J.J., Gaver, K.M., \& Austin, J.R. (1995). Additional evidence on bonus plans and income management. Journal of accounting and Economics, 19(1), 3-28.

George, N.E. (1988). Management earnings forecast disclosure: An empirical study of factors influencing the decision. City University of New York.

Gunny, K.A. (2010). The relation between earnings management using real activities manipulation and future performance: Evidence from meeting earnings benchmarks. Contemporary Accounting Research, 27(3), 855-888.

Hang, J.C., \& Wang, S.W. (1998). Political cost and earnings management of oil companies during 1990-Persian gulf crisis. Accounting Review, 73(1), 103-117.

Hazarika, S., Karpoff, J. M., \& Nahata, R. (2012). Internal corporate governance, CEO turnover, and earnings management. Journal of Financial Economics, 104(1), 44-69.

Healy, P.M. (1985). The effect of bonus schemes on accounting decisions. Journal of Accounting and Economics, 7(1-3), 85-107.

Healy, P.M., \& Wahlen, J.M. (1999). A review of the earnings management literature and its implications for standard setting. Accounting Horizons, 13(4), 365.

Holthausen, R.W., Larcker, D.F., \& Sloan, R G. (1995). Annual bonus schemes and the manipulation of earnings. Journal of accounting and economics, 19(1), 29-74.

Holthausen, R.W., Larcker, D.F., \& Sloan, R.G. (1995). Annual bonus schemes and the manipulation of earnings. Journal of Accounting and Economics, 19(1), 29-74.

Jaggi, B., \& Lee, P. (2002). Earnings management response to debt covenant violations and debt restructuring. Journal of Accounting, Auditing and Finance, 17(4), 295-324.

Jones, J.J. (1991). Earnings management during import relief investigations. Journal of Accounting Research, 193-228.

Jones, S.H., \& Davidson, R.A. (2007). Measuring the problem-solving abilities of accounting and other business students: a comparison and evaluation of three methods. Accounting Education: An International Journal, 16(1), 65-79.

Kalyta, P. (2009). Accounting discretion, horizon problem, and CEO retirement benefits. The Accounting Review, 84(5), 1553-1573.

Kim, S., \& Ng, J. (2018). Executive Bonus Contract Characteristics and Share Repurchases. The Accounting Review, 93(1), 289-316. 
Legoria, J. (1997). Political costs, health care reform and earnings management in the pharmaceutical industry. University of Arkansas.

Lin, S. (2006). Classificatory earnings management and meeting or beating analysts' earnings forecasts. The University of Texas at Dallas.

Murphy, K.J. (1999). Executive compensation. Handbook of Labor Economics, (3), 2485-2563.

Murphy, K.J., \& Zimmerman, J.L. (1993). Financial performance surrounding CEO turnover. Journal of Accounting and Economics, 16(1-3), 273-315.

Pourciau, S. (1993). Earnings management and nonroutine executive changes. Journal of Accounting and Economics, 16(1-3), 317-336.

Prencipe, A., Markarian, G., \& Pozza, L. (2008). Earnings Management in Family Firms: Evidence From R\&D Cost Capitalization in Italy. Family Business Review, 21(1), 71-88.

Roychowdhury, S. (2006). Earnings management through real activities manipulation. Journal of Accounting and Economics, 42(3), 335-370.

Strong, J.S., \& Meyer, J.R. (1987). Asset writedowns: Managerial incentives and security returns. The Journal of Finance, 42(3), 643-661.

Vorst, P. (2016). Real earnings management and long-term operating performance: The role of reversals in discretionary investment cuts. Accounting Review: A Quarterly Journal of the American Accounting Association, 91(4), 9.

Wang, S.W., \& Chen, S.Y. (2012). the motivation for tax avoidance in earnings management. Scientific Research, $447-450$

Watts, R., \& Zimmerman, J. (1990). Positive Accounting Theory: A Ten Year Perspective. The Accounting Review, 65(1), 131-156.

Watts, R.L., \& Zimmerman, J. (1986). Positive accounting theory. Englewood Cliffs, NJ: Prentice-Hall.

\section{Appendix A}

The table shows that except for $M C A P_{t}$, the estimated coefficients on all other variables are significantly positive at 1 percent level, and are consistent with those reported by Vorst (2016) and Gunny (2010). My regression coefficient on $M C A P_{t}$ is not significant, while Table 1 (Vorst 2016, p. 1224) shows a regression $M C A P_{t}$ of 0.0001 $(\mathrm{t}-\mathrm{value}=3.23)$. This inconsistent result is likely due to different sample period. When I restrict my sample period to Vorst (2016)'s sample period 1983 to 2012, the regression coefficient on $M C A P_{t}$ is significant at 10 percent level.

Table A. Estimation of the Real Earnings Management Models

\begin{tabular}{|c|c|c|}
\hline Model & $\underline{R \& D_{t}} \underline{\underline{\prime A}} \underline{t-1}$ & $\underline{S G \& A_{t}} \underline{\underline{A}} \underline{\underline{t}-\underline{1}}$ \\
\hline \multirow[t]{2}{*}{ Intercept } & $-0.002 * * *$ & $0.300 * * *$ \\
\hline & $(-3.95)$ & $(41.46)$ \\
\hline \multirow[t]{2}{*}{$1 / A_{t-1}$} & $0.135 * * *$ & $4.322 * * *$ \\
\hline & $(10.53)$ & $(12.89)$ \\
\hline \multirow[t]{2}{*}{$M C A P_{t}$} & 0.001 & $-0.219 * * *$ \\
\hline & (1.56) & $(-21.14)$ \\
\hline \multirow[t]{2}{*}{ TOBINSQ $Q_{t}$} & $0.003 * * *$ & $0.028 * * *$ \\
\hline & (15.39) & (12.69) \\
\hline \multirow[t]{2}{*}{ INFUNDS $S_{l} / A_{t-1}$} & $0.022 * * *$ & $0.493 * * *$ \\
\hline & $(14.21)$ & (21.39) \\
\hline$R \& D_{t} / A_{t-1}$ & $0.961 * * *$ & \\
\hline
\end{tabular}


(210.36)

$\triangle S A L E_{t} / A_{t-1}$ $0.126^{* * *}$

$\triangle S A L E_{t} / A_{t-1} * N E G D S A L E_{t}$

Average $\mathrm{R}^{2}$ 0.906 0.526

No. Industry Years

211

$*, * *, * * *$ Indicate statistical significance at the 10 percent, 5 percent, and 1 percent levels, respectively (two-tailed).

This table reports the results of the estimation of the real earnings management model of R\&D and SG\&A expenditure. Equation (1) is estimated by two-digit historical SIC code each year. The sample contains all firms, excluding that operate in financial or regulated industries, with available data on Compustat from the period 2006-2017. The reported coefficients are calculated as the average of coefficients of each industry-year regression. t-statistics are calculated as the mean coefficients divided by the standard error of the mean and are reported in parentheses below each coefficient. All variables are winsorized at 1st and 99th percentiles before running the regressions.

The variables are defined as follows:

$R \& D_{t}=$ research and development expense for year $\mathrm{t}$;

$1 / A_{t-1}=$ lagged total assets;

$M C A P_{t}=$ natural logarithm of the market value of equity;

TOBINSQ $Q_{t}=$ a measure of investment opportunity and is calculated as the sum of total debt, market value and preferred stock and divided by total assets;

$I N F U N D S_{t}=$ a measure of funds available for investment and is calculated as the sum of extraordinary items, depreciation expense, and research and development expense;

$\triangle S A L E_{t}=$ calculated as the current year's slaes minus the last year's sales;

$N E G D S A L E_{t}=$ an indicator variable that equals 1 if the change in sales is negative, and 0 otherwise.

\section{Copyrights}

Copyright for this article is retained by the author(s), with first publication rights granted to the journal.

This is an open-access article distributed under the terms and conditions of the Creative Commons Attribution license (http://creativecommons.org/licenses/by/4.0/). 